\title{
SISTEM PAKAR BERBASIS WEB UNTUK MENDIAGNOSA PENYAKIT KULIT
}

\author{
Paryati \\ Jurusan Teknik Informatika UPN "Veteran" Yogyakarta \\ Jl. Babarsari no 2 Tambakbayan 55281 Yogyakarta Telp (0274)-485323 \\ e-mail : yaya upn cute@yahoo.com
}

\begin{abstract}
Human skin consists of various layers either protected or very sensitive to outside attack such as from the surrounding. Today there are many inventions in connection with the skin disease where many skin bacterias and viruses attack the human either from the surroundings, climate or temperature even from direct contact with the wet nurse or mother of virus. Skin disease which is suffered by the people is easy to wide spread because of lack information and knowledge about skin disease. This system is made in order that the skin sufferers know and understand the kind of skin disease which they get and this system gives some solutions and preventions in accordance with the disease circle. The method which is used in the plan and development is waterfall method. The application which is used to make this expert system programme is Dreamweaver, XAMPP, Adope Photoshop, Mysql, Opera. The result of this research is in the form of application programme that can help the user know the kinds of skin disease and also know the technique or theraphy and the way of prevention.

Key word : Fordward Chaining, Backward Chaining, Web, Waterfall.

Kulit manusia terdiri dari berbagai lapisan, baik itu lapisan yang terlindungi maupun lapisan yang sangat rentan terhadap serangan dari luar seperti dari lingkungan. Belakangan ini terdapat penemuan-penemuan yang berhubungan dengan penyakit kulit dimana terdapat banyak cara bakteri dan virus kulit menyerang manusia seperti dari keadaan lingkungan, iklim atau suhu bahkan dari kontak langsung dengan inang atau induk virus. Penyakit kulit yang diderita oleh masyarakat saat ini cepat sekali menyebar dikarenakan kurangnya informasi dan pengetahuan tentang penyakit kulit. Oleh karena itu peneliti membuat riset sistem pakar untuk mendiagnosa penyakit kulit dengan menggunakan metode fordward dan backward chaining berbasis web disertai cara pencegahan dan pengobatannya. Sistem ini dibuat agar para penderita penyakit kulit mengerti dan memahami jenis penyakit kulit apa yang diderita dan system ini memberikan beberapa solusi pencegahan sesuai dengan tingkatan penyakit yang ada sekarang ini. Metode yang digunakan adalah Metode waterfall. Aplikasi yang digunakan untuk membuat program sistem pakar ini adalah Dreamweaver MX, XAMPP, Adobe Photoshop, MySQL, Opera / Mozzila Firefox. Hasil dari riset ini adalah berupa program aplikasi yang dapat membantu user mengetahui jenis penyakit kulit yang diderita serta mendapat informasi yang luas mengenai penyakit kulit serta mengetahui teknik pengobatan dan cara pencegahannya.

Kata Kunci : Fordward Chaining, Backward Chaining, Web, Waterfall.
\end{abstract}

\section{PENDAHULUAN}

Kulit manusia terdiri atas lapisan epidermis dan lapisan dermis. Kulit berfungsi sebagai alat eskresi karena adanya kelenjar keringat yang terletak di lapisan dermis. Epidermis tersusun atas lapisan tanduk dan lapisan Malpighi. Lapisan korneum merupakan lapisan kulit mati, yang dapat mengelupas dan digantikan oleh sel-sel baru. Lapisan Malpighi terdiri atas lapisan spinosum dan lapisan germinativum. Lapisan spinosum berfungsi menahan gesekan dari luar. Lapisan germinativum mengandung sel-sel yang aktif membelah diri, mengantikan lapisan selsel pada lapisan korneum. Pada saat ini banyak penemuan penyakit kulit yang menyerang manusia. Maka dengan kemajuan teknologi komputer dapat membantu manusia dalam berbagai bidang salah satu diantaranya adalah sistem pakar. Sistem pakar merupakan program komputer yang dirancang untuk memodelkan kemampuan menyelesaikan masalah seperti seorang pakar. Dengan perkembangan sistem pakar dapat dibuat aplikasi sistem pakar yang dapat mendiagnosa penyakit kulit berdasarkan gejala-gejala yang diderita oleh pasien dan cara pengobatannya. 
Sistem ini mendiagnosa jenis penyakit kulit berdasarkan gejala-gejala yang dialami. Jenis penyakit kulit yang terdapat dalam sistem ini yaitu: Basal Cell Carcinoma, Atopic Dermatitis, Allergic Contact Dermatitis, Berloque Dermatitis, Bateman's purpura, Acrochordons, Angioma, Seborrheic Keratosis, Tinea pedis, Actinic keratosis, Acanthosis Nigricans. Pengobatan yang dilakukan berdasarkan identifikasi penyakit kulit yang dialami oleh user yang telah diteliti sebelumnya oleh para pakar kulit untuk tiap penyakit kulit ada yang berupa saran, anjuran, imbauan. Metodologi yang digunakan dalam pengembangan system pakar ini adalah metode waterfall terdiri dari: system engineering, analysis, design, coding, testing dan maintenance (Pressman, 2002). Pembuatan sistem ini sampai tahap pengujian dan program berhasil dijalankan sesuai dengan fungsinya.

\section{TINJAUAN PUSTAKA}

\section{Sistem Pakar}

Sistem Pakar adalah sistem berbasis komputer yang menggunakan pengetahuan, fakta dan teknik penalaran dalam memecahkan masalah yang biasanya hanya dapat dipecahkan oleh seorang pakar dalam bidang tersebut (Kusrini, 2006).

Keunggulan Sistem Pakar dan Kekurangan Sistem Pakar

Keunggulan sistem pakar (Kusumadewi, 2003) yaitu: menyimpan pengetahuan dan keahlian seorang pakar, meningkatkan output dan produktivitas, mampu mengambil dan melestarikan keahlian para pakar, mampu mengakses pengetahuan, mampu bekerja dengan informasi yang tidak lengkap dan mengandung ketidakpastian, menghemat waktu dalam pengambilan keputusan. Kelemahan sistem pakar (Arhami, 2004) yaitu: pengetahuan tidak selalu bisa didapat dengan mudah, keterbatasan pakar dan terkadang pendekatan yang dimiliki pakar berbeda-beda, kesulitan dalam pembuatan sistem pakar yang berkualitas tinggi dan memerlukan biaya yang sangat besar dalam pengembangan dan pemeliharaannya, perlu dilakukan pengujian secara teliti sebelum digunakan.

\section{Struktur Sistem Pakar}

Sistem pakar terdiri dari dua bagian pokok yaitu : lingkungan pengembangan dan lingkungan konsultasi (Kusumadewi, 2003).



Gambar 1. Struktur Sistem Pakar.

\section{Basis Pengetahuan}

Basis pengetahuan yang digunakan dalam system pakar ini menggunakan Rule-Based Reasoning yaitu pengetahuan direpresentasikan dengan menggunakan aturan berbentuk ifthen.

\section{Mesin Inferensi}

Terdapat dua pendekatan untuk mengontrol inferensi dalam sistem pakar berbasis aturan (Archami, 2004) yaitu: Forward Chaining, penalaran dimulai dari fakta terlebih dahulu untuk menguji kebenaran hipotesis. Pelacakan ke depan mencari fakta yang sesuai dengan bagian IF dari aturan IF-THEN. Dan Backward Chaining, penalaran dimulai dari hipotesis terlebih dahulu dan untuk menguji kebenaran hipotesis tersebut harus dicari fakta-fakta yang ada. Pelacakan ke belakang mencari fakta yang sesuai dengan bagian IF-AND dari aturan IF-ANDTHEN.Kedua metode inferensi tersebut dipengaruhi oleh tiga macam penulusuran, yaitu Depthfirst Search,Breadth-first Search, Breadth-first search. 


\section{Penyakit Kulit}

Kulit manusia terdiri atas lapisan epidermis dan dermis. Kulit berfungsi sebagai alat eskresi karena adanya kelenjar keringat yang terletak di lapisan dermis. Epidermis tersusun atas lapisan tanduk dan lapisan Malpighi. Lapisan korneum merupakan lapisan kulit mati, yang dapat mengelupas dan digantikan oleh sel-sel baru. Lapisan Malpighi terdiri atas lapisan spinosum dan lapisan germinativum. Lapisan spinosum berfungsi menahan gesekan dari luar. Lapisan germinativum mengandung sel-sel yang aktif membelah diri, mengantikan lapisan selsel pada lapisan korneum. Lapisan Malpighi mengandung pigmen melanin yang memberi warna pada kulit. Lapisan ini mengandung pembuluh darah, akar rambut, ujung syaraf, kelenjar keringat, dan kelenjar minyak. Kelenjar keringat menghasilkan keringat. Banyaknya keringat yang dikeluarkan dapat mencapai $2.000 \mathrm{ml}$ setiap hai, tergantung pada kebutuhan tubuh dan pengaturan suhu. Keringat mengandung air, garam, dan urea. Fungsi lain sebagai alat ekskresi yaitu sebagai organ penerima rangsangan, pelindung terhadap kerusakan fisik, penyinaran, bibit penyakit dan untuk pengaturan suhu tubuh.

\section{ANALISIS DAN PERANCANGAN}

\section{Analisis Kebutuhan sistem}

Sistem pakar yang dibagun untuk mendiagnosa penyakit dan cara penyembuhannya. Sistem ini bertujuan membantu user apat mengetahui jenis penyakit yang diderita dan penyembuhannya melalui mandi air belerang dan ramuan tradisional atau obat tradisional, serta informasi ramuan obat guna membantu proses penyembuhannya. Data rekomendasi yang dihasilkan dalam sistem ini dilengkapi dengan jenis penyakit, gejala penyakit dan cara penyembuahannya sehingga user dapat mengetahui penyakit yang diderita dan cara pengobatannya. Sistem akan menganalisis jawaban dari setiap pertanyaan yang diberikan agar dapat memperoleh jawaban berdasarkan basis pengetahuan yang terdapat dalam sistem pakar ini. Sebelum menganalisis jawaban, sistem terlebih dahulu memberikan sejumlah pertanyaan kepada user melalui interface tentang gejala penyakit yang diderita. Sistem akan menganalisis jawaban dari user dengan melakukan proses pelacakan pada basis pengetahuan.

\section{Perancangan Proses}

Perancangan DAD digunakan untuk menggambarkan hirarki proses yang ada dan aliran data antar proses dalam sistem ini. DAD level 0 mempresentasikan semua elemen sistem dengan sebuah proses tunggal dengan data input dan output yang ditunjukkan oleh anak panah yang masuk dan keluar secara berurutan. Sistem yang dibangun memiliki dua entitas luar yaitu admin dan user. Admin berwenang untuk melakukan update data. User hanya bisa memakai sistem dan tidak berwenang mengupdate data. User hanya input data ke sistem, sistem akan memberikan keluaran pada user.

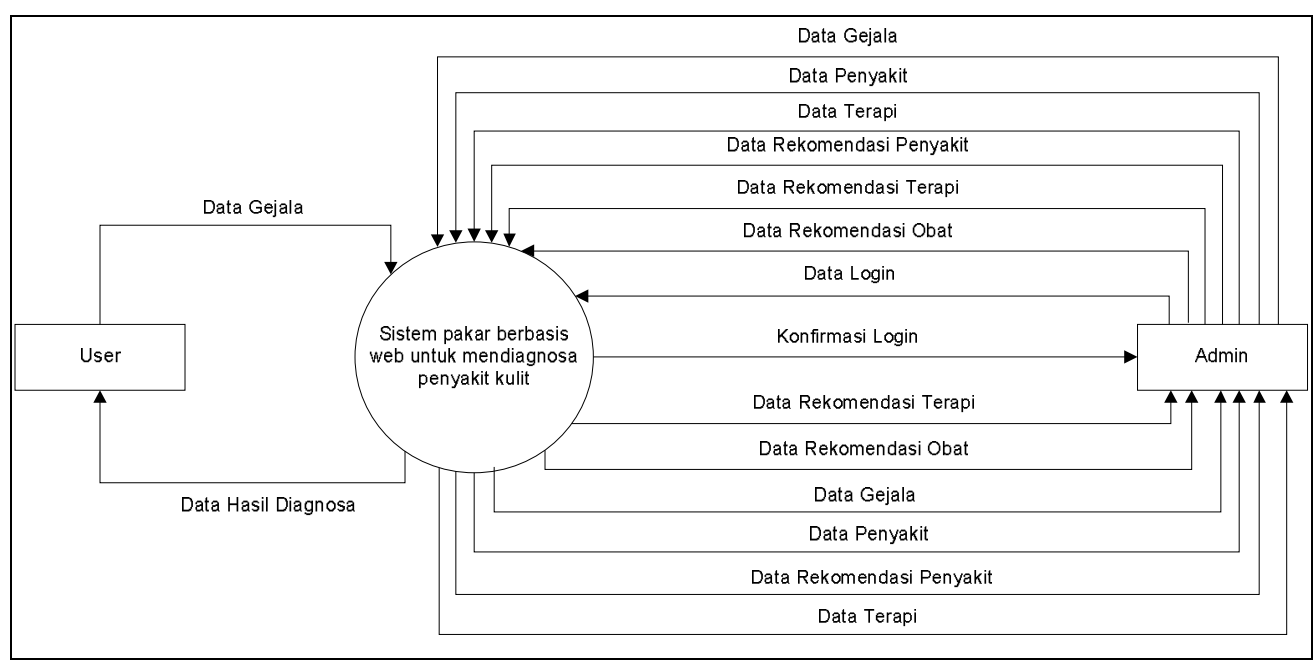

Gambar 2. DAD Level 0 


\section{Relasi Antar Tabel}

Relasi antar tabel menggambarkan hubungan antara tabel satu dengan tabel yang lain. Bentuk relasi pada sistem adalah one to one, one to many, dan many to one.

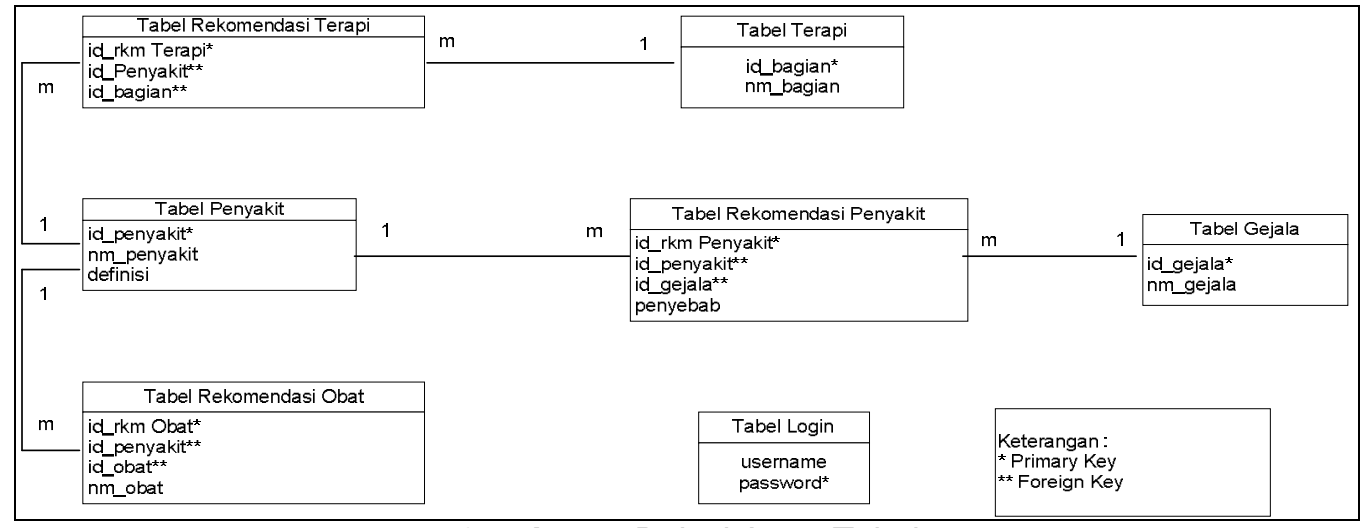

Gambar 3. Relasi Antar Tabel

\section{Akuisi Pengetahuan}

Proses akuisi pengetahuan dilakukan dengan cara mengumpulkan pengetahuan tentang jenis penyakit disertai dengan gejala, penyebab dan pengobatan. Pengetahuan yang harus diakuisisikan adalah gejala yang diderita.

\section{Perancangan Sistem}

Aplikasi sistem pakar ini dirancang untuk mengambil dan mengidentifikasi data-data keseluruhan mengenai definisi penyakit, penyebab penyakit, pengobatan, gejala-gejala penyakit.Tahap perancangan sistem pakar ini terdiri dari lima perancangan yaitu representasi pengetahuan, mesin inferensi, DAD, basis data dan perancangan antar muka.

\section{Perancangan Representasi Pengetahuan}

Representasi pengetahuan yang dilakukan untuk membangun aplikasi ini menggunakan kaidah produksi berbasis aturan (rule). Struktur rule mempunyai dua bagian yaitu antesendent dan consequents. Konklusi yang dinyatakan pada bagian THEN dinyatakan benar, jika bagian IF pada sistem tersebut juga benar atau sesuai dengan aturan tertentu.

Kaidah produksi pada sistem ini menggunakan dua penelusuran yaitu Forward Chaining untuk kaidah produksi penyakit dan Backward Chaining untuk kaidah produksi terapi pemijatannya. Kaidah produksi untuk implementasi adalah :

Kaidah Produksi Penyakit

Penyakit yang dibahas dalam implementasi ini antara lain penyakit Basal Cell Carcinoma, Atopic Dermatitis, Allergic Contact Dermatitis, Berloque Dermatitis, Berloque Dermatitis, Bateman's purpura, Acrochordons, Angioma, Seborrheic Keratosis, Tinea pedis, Actinic keratosis, Acanthosis Nigricans. Berikut kaidah produksi penyakit sesuai dengan gejalagejalanya :

a. Kaidah produksi penyakit Basal Cell Carcinoma

If Sakit Basal Cell Carcinoma

and Kulit memerah

and Kulit gatal

and Kulit bersisik

and Kulit menggumpal

then Penyakit Basal Cell Carcinoma

b. Kaidah untuk penyakit Basal Cell Carcinoma

if Biopsi

and Pembedahan Karsinoma sel

then identifikasi penyakit Basal Cell Carcinoma 

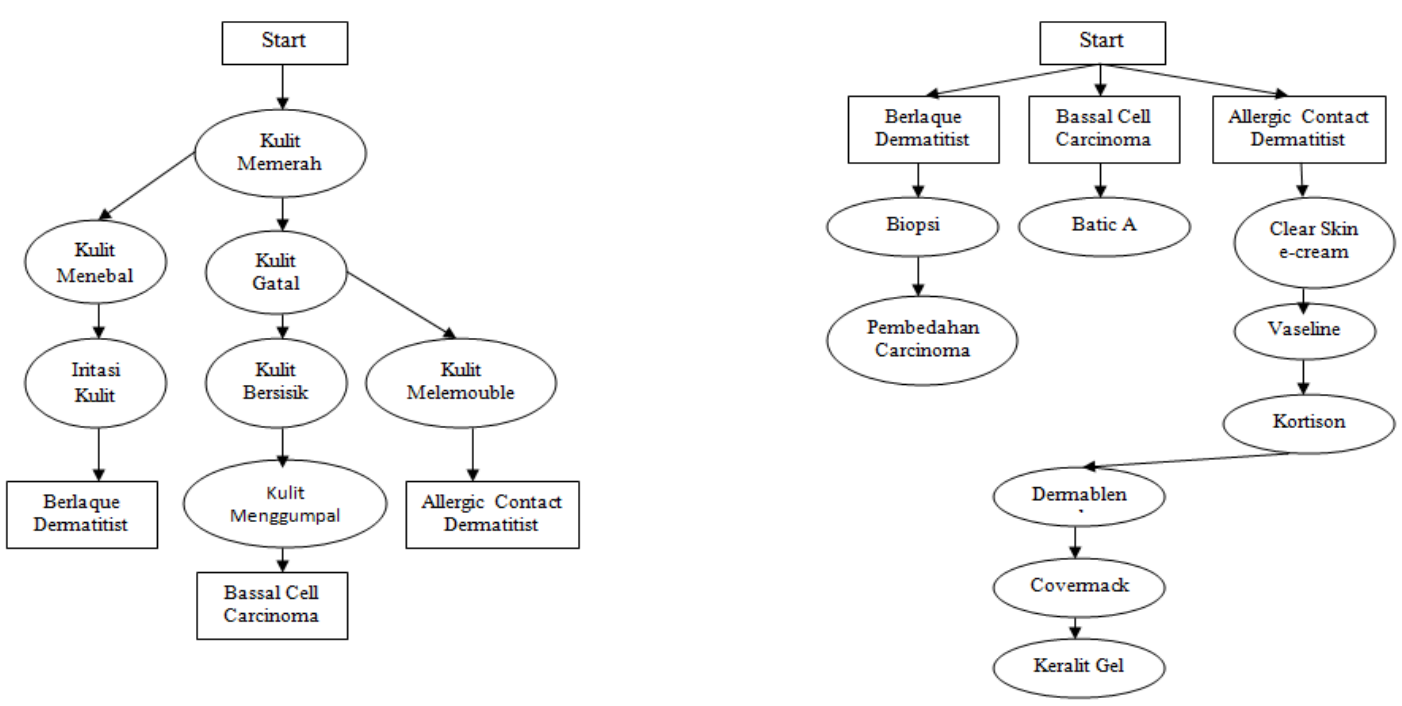

Gambar 4.Contoh Pelacakan Fordward Chaining

Gambar 5.Contoh Pelacakan Backward Chaining

Tabel 1. Tabel Akuisisi Hubungan Gejala dan Penyakit Kulit

\begin{tabular}{|c|c|c|c|c|c|c|c|c|c|c|c|}
\hline No & Id Gejala & Gejala & $\begin{array}{c}\begin{array}{c}\text { Bassal } \\
\text { Cell }\end{array} \\
\end{array}$ & $\begin{array}{c}\text { Atopic } \\
\text { Dermatitis }\end{array}$ & $\begin{array}{l}\text { Allergic } \\
\text { Contact }\end{array}$ & \begin{tabular}{|l} 
Berloque \\
Dermatitis
\end{tabular} & \begin{tabular}{|c|} 
Batemans \\
Purpura \\
\end{tabular} & Acrocordons & Angioma & \begin{tabular}{|l} 
Seborheic \\
Keratosis \\
\end{tabular} & \begin{tabular}{|l|} 
Tinea \\
Pedis \\
\end{tabular} \\
\hline 1 & 2 & 3 & 4 & 5 & 6 & 7 & 8 & 9 & 10 & 11 & 12 \\
\hline 1 & G1 & Kulit memerah & $x$ & $x$ & $x$ & $x$ & $x$ & $x$ & $x$ & & \\
\hline 2 & G2 & Kulit gatal & $x$ & $x$ & $x$ & & & & & $x$ & $x$ \\
\hline 3 & G3 & Kulit menebal & & & & $x$ & & & & & \\
\hline 4 & G4 & Kulit bersisik & $x$ & $x$ & & & & & & & \\
\hline 5 & G5 & Kulit berkerut & & & & & $x$ & & & & \\
\hline 6 & G6 & Hiperpigmentasi & & & & & & $x$ & & & \\
\hline 7 & G7 & Kulit lipatan & & & & & & $x$ & & & \\
\hline 8 & G8 & Muncul kutil di kulit & & & & & & $x$ & & $x$ & \\
\hline 9 & G9 & kulit berbercak & & & & & $x$ & & & & \\
\hline 10 & G10 & Kulit melepuh & & & $x$ & & & & & & $x$ \\
\hline 11 & G11 & Kulit menggumpal & $X$ & & & & & & $X$ & & \\
\hline 12 & G12 & Kulit kasar & & & & & & & & & $x$ \\
\hline 13 & G13 & Kulit mengelupas & & & & & & & & & $x$ \\
\hline 14 & G14 & Kulit pecah-pecah & & & & & & & & & $x$ \\
\hline 15 & G15 & Kulit sakit & & & & & & & & & $x$ \\
\hline 16 & G16 & Kulit membengkak & & & & & & & & & $x$ \\
\hline 17 & G17 & Kulit tipis & & & & & $x$ & & & & \\
\hline 18 & G18 & Iritasi kulit & & & & $x$ & & & & & \\
\hline 19 & G19 & Permukaan halus & & & & & & & & $x$ & \\
\hline
\end{tabular}


Tabel 2. Tabel Akuisisi Hubungan Obat dan Penyakit Kulit

\begin{tabular}{|c|c|c|c|c|c|c|c|c|c|c|c|}
\hline No & Id Gejala & Gejala & \begin{tabular}{|c|} 
Bassal \\
Cell \\
Carcinom
\end{tabular} & \begin{tabular}{|c|} 
Atopic \\
Dermatitis \\
$t$
\end{tabular} & \begin{tabular}{|c|} 
Allergic \\
Contact \\
Dermatitis
\end{tabular} & \begin{tabular}{|c|} 
Berloque \\
Dermatitis \\
$\mathrm{t}$
\end{tabular} & \begin{tabular}{|c} 
Batemans \\
Purpura
\end{tabular} & Acrocordons & Angioma & $\begin{array}{l}\text { Seborheic } \\
\text { Keratosis }\end{array}$ & $\begin{array}{l}\text { Tinea } \\
\text { Pedis }\end{array}$ \\
\hline 1 & 2 & 3 & 4 & 5 & 6 & 7 & 8 & 9 & 10 & 11 & 12 \\
\hline 1 & G1 & Betin A & & & & $x$ & & & & & \\
\hline 2 & $\mathrm{G} 2$ & $15 \%$ Urea & & & & & & & & & \\
\hline 3 & G3 & JHyprocyacidaita & & & & & & & & & \\
\hline 4 & G4 & Asam salisilat & & & & & & & & & \\
\hline 5 & G5 & Picolinatakromi & & & & & & $\mathrm{x}$ & & & \\
\hline 6 & G6 & Natrol Chromee & & & & & & $x$ & & & \\
\hline 7 & G7 & Hydrocortizone & & & $x$ & & & & & & \\
\hline 8 & G8 & JEpitreX & & & $\mathrm{x}$ & & & & & & \\
\hline 9 & G9 & |Elektrodesicatine & & & & & & & $x$ & & \\
\hline 10 & G10 & Liquid nitrogen & & & & & & & $x$ & & \\
\hline 11 & G11 & Loperamin Cream & & & & & & & & & $x$ \\
\hline 12 & $\mathrm{G} 12$ & Athlete's toot & & & & & & & & & $x$ \\
\hline 13 & G13 & Griceofulfin & & & & & & & & & $x$ \\
\hline 14 & G14 & Skin-Ecream & & $\mathrm{x}$ & & $x$ & & & & & \\
\hline 15 & G15 & Vaseline & & $x$ & & $x$ & & & & & \\
\hline 16 & G16 & Hidrocortizone & & $\bar{x}$ & & & & & & & \\
\hline 17 & G17 & Liquid nitrogen & & & & & & & & $x$ & \\
\hline 18 & G18 & BIopsi & $\mathrm{x}$ & & & & & & & & \\
\hline 19 & G19 & Bedan Carsinoma & $\bar{x}$ & & & & & & & & \\
\hline 20 & G20 & Miconazole Cream & & & & & $\mathrm{x}$ & & & & \\
\hline 21 & G21 & Alfa Hydroacid & & & & & $x$ & & & & \\
\hline 22 & G22 & Dermablend & & & & $x$ & & & & & \\
\hline 23 & G23 & Covermeck & & & & $x$ & & & & & \\
\hline 24 & G24 & Keralit Gel & & & & $x$ & & & & & \\
\hline
\end{tabular}

\section{HASIL DAN PEMBAHASAN}

Hasil keluaran dari sistem ini adalah berupa gambar dan keterangan untuk mengidentifikasii penyakit dengan memasukan gejala-gejala pada halaman konsultasi. Sedangkan untuk mengidentifikasi penyakit memiliki keluaran nama pasien, nama penyakit, nama gejala dan keterangan penyebab, ciri-ciri penderita, cara pengobatan, terapi, dan.

Implementasi Pembangunan Aplikasi

Halaman konsultasi berisi diagnose penyakit dengan mengajukan beberapa pertanyaan yang harus dijawab oleh user. Berikut ini merupakan tampilan halaman konsultasi.

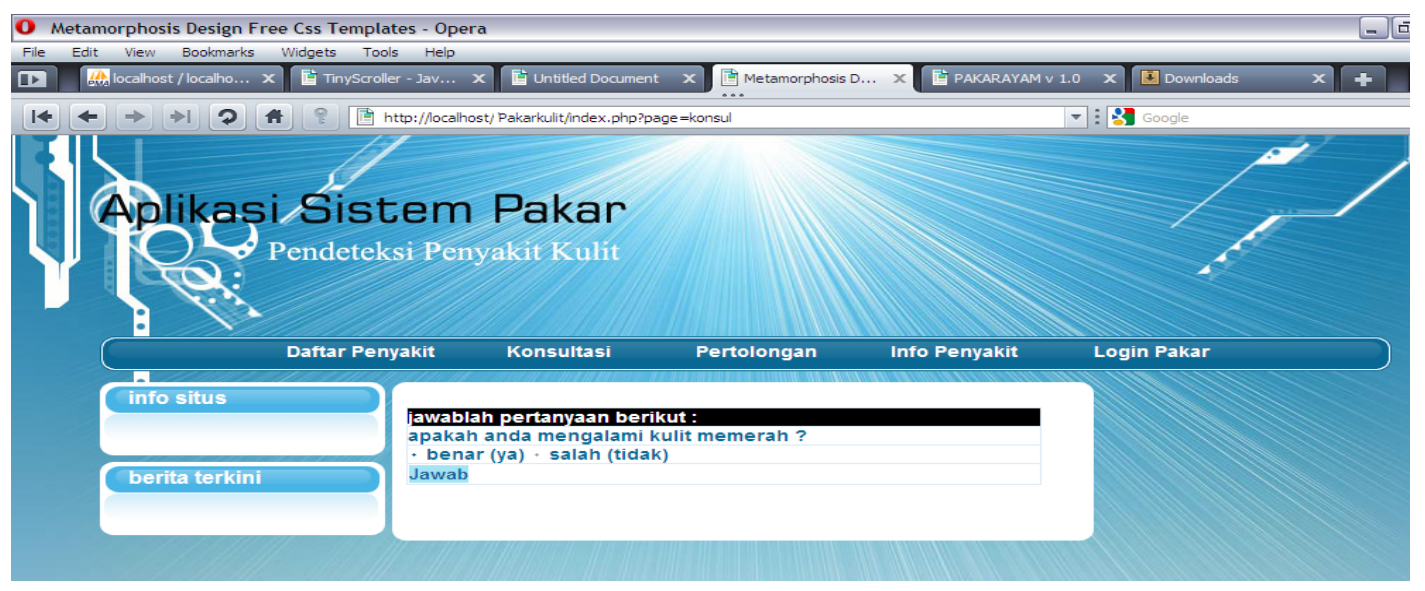

Gambar 6. Tampilan halaman konsultasi.

Halaman daftar penyakit memuat macam-macam jenis penyakit kulit. Ini merupakan tampilan halaman daftar penyakit. 


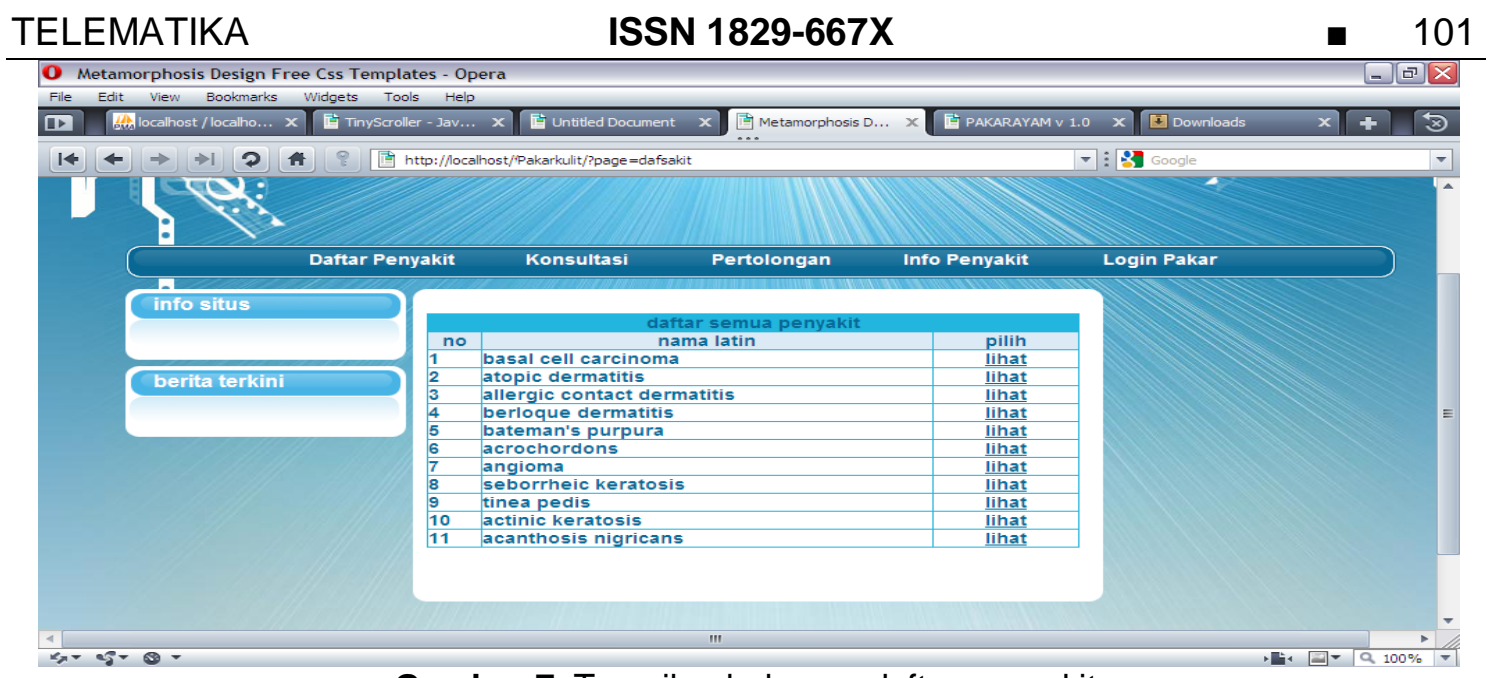

Gambar 7. Tampilan halaman daftar penyakit.

Halaman gejala penyakit memuat gejala-gejala dari suatu macam penyakit kulit yang telah dipilih. Berikut ini merupakan tampilan halaman gejala penyakit.

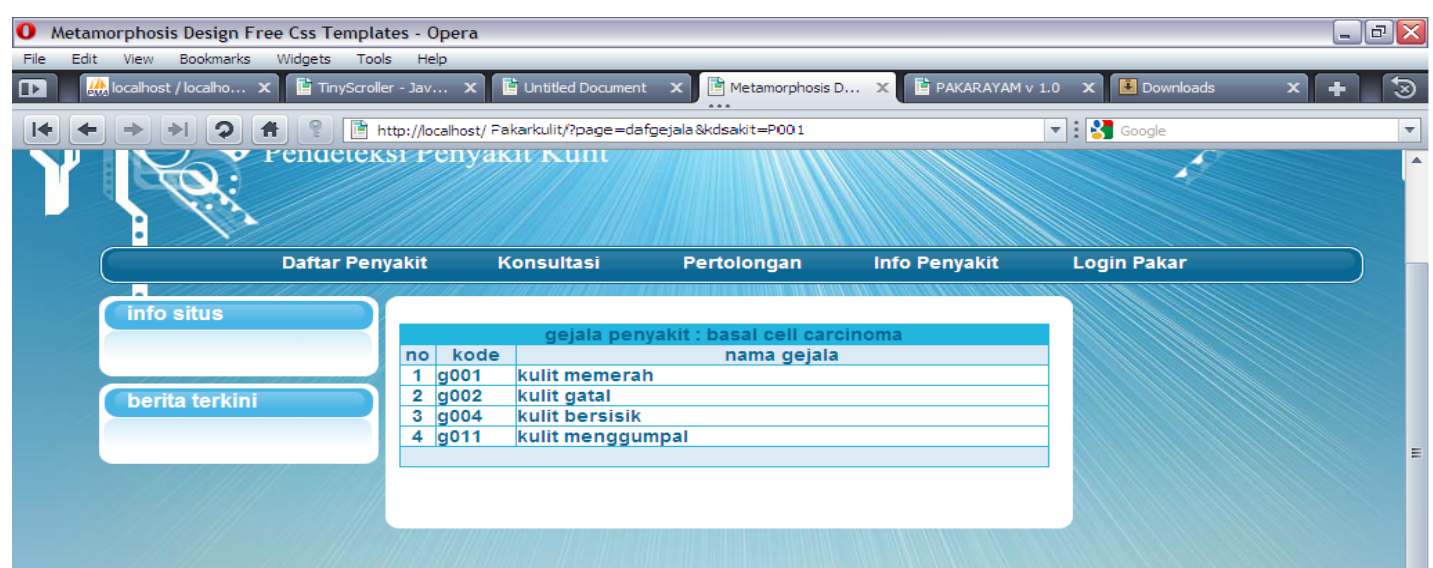

Gambar 8. Tampilan halaman gejala penyakit.

Halaman data pasien berisi nama pasien, jenis kelamin, alamat dan pekerjaan. Berikut ini merupakan tampilan halaman data pasien.

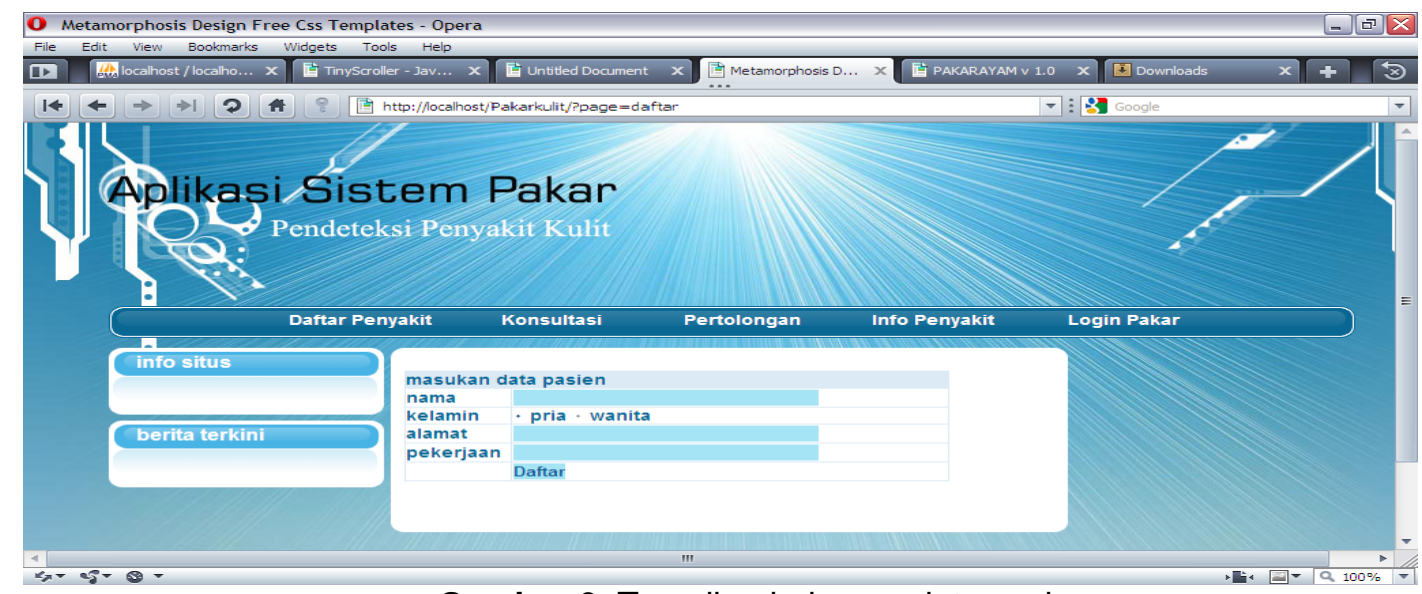

Gambar 9. Tampilan halaman data pasien.

Halaman analisa hasil berupa kesimpulan yang diambil oleh sistem pakar berdasarkan gejala-gejala yang telah disebutkan oleh user. Berikut tampilan halaman analisa hasil. 


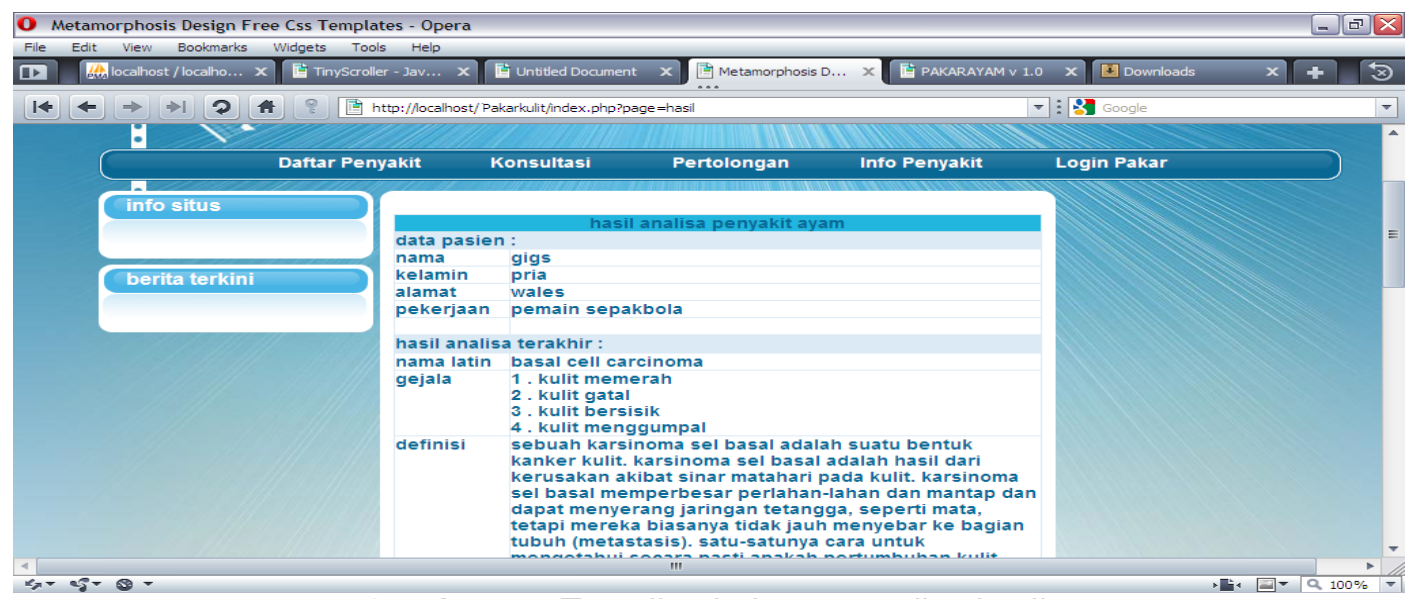

Gambar 10. Tampilan halaman analisa hasil.

Halaman login merupakan halaman yang hanya bisa diakses oleh administrator. untuk keperluan update data, tambah data maupun hapus data.

\section{KESIMPULAN}

Berdasarkan hasil penelitian ini maka dapat ditarik kesimpulan sebagai berikut :

a. Memberikan informasi kepada user mengenai penyakit kulit yang dideritanya (diagnosa awal) berdasarkan gejala-gejala yang diberikan.

b. Memahami dan memperoleh model pengetahuan untuk gejala-gejala penyakit kulit.

c. Membantu dalam melakukan identifikasi penyakit kulit secara dini, melalui pengolahan computer, sehingga penanganan lebih lanjut terhadap penyakit tersebut dapat dengan cepat dilakukan.

d. Memberikan informasi pengobatan yang bisa dilakukan dan cara mengatasinya.

e. Data yang terdapat pada sistem dapat diupdate atau ditambah sesuai dengan kebutuhan.

\section{DAFTAR PUSTAKA}

Arhami, M, 2005, "Konsep Dasar Sistem Pakar", Andi Offset, Yogyakarta.

Harahap, M, 2000, "Ilmu Penyakit Kulit", Jakarta : Hipokrotes.

Kadir, A, 2004, "Dasar Pemrograman Web Dinamis dengan (JSP) Java Server Pages", Andii Offset, Yogyakarta.

Kusrini, 2006, "Sistem Pakar dan Teori Aplikasi", Andi Offset, Yogyakarta.

Kusumadewi, S, 2003, "Artificial Intellegence (Teknik dan Aplikasinya)", Graha Ilmu, Yogyakarta.

Mulyawan, R \& dkk, "Sistem dan Penyembuhan Penyakit Kulit", AMIKOM, Yogyakarta.

Nugroho, B, 2004, "Aplikasi Pemrograman Web Dinamis dengan PHP dan MySQL", Gava Media, Yogyakarta.

Prasetyo, D.D, 2003, "Administrasi Database Server MySQL", Elex Media Komputindo, Jakarta.

Pressman, R, 2002, "Rekayasa Perangkat Lunak Pendekatan Praktisi (Buku Satu)", Andi Offset, Yogyakarta.

Sunyoto, Andi, 2007, "Membangun Web dengan Teknologi Asynchronouse JavaScript \& XML", Andi, Yogyakarta.

Sutarman, 2003., "Membangun Aplikasi Web dengan PHP dan MySQL", Graha IImu, Yogyakarta.

Yuwono,B \& dkk, 2008, "Sitem Pakar Berbasis Web Untuk Identifikasi Jenis Dan Penyakit Pada Bunga Mawa” Prosiding Semnasif, UPN”Veteran” Yogyakarta. 